\title{
PENDAPATAN DAN KESEJAHTERAAN RUMAH TANGGA PETANI UBIKAYU DI PROVINSI LAMPUNG
}

\author{
Wan Abbas Zakaria ${ }^{1}$, Teguh Endaryanto ${ }^{2}$, Lidya Sari Mas Indah ${ }^{3}$, \\ I Rani Mellya Sari ${ }^{4}$, dan Abdul Mutolib ${ }^{5}$ \\ 1,2,3,4)Program Studi Agribisnis, Fakultas Pertanian, Universitas Lampung \\ 5)Progam Studi Penyuluhan Pertanian, Fakultas Pertanian, Universitas Lampung \\ JL Sumantri Brojonegoro I, Gedong Meneng, Kec. Rajabasa, Kota Bandar Lampung, Indonesia \\ e-mail : 1)wan_abbas@yahoo.com
}

(Diterima 25 November 2019/Disetujui 31 Desember 2019)

\begin{abstract}
This study aims to (1) analyze the level of income and (2) analyze the factors that influence the level of household welfare of cassava farmers. The study was conducted in Gunung Agung Village, Terusan Nunyai District, Central Lampung Regency with a survey method. The sample of farmers 78 respondents was taken by proportional stratified simple random sampling. Data analysis using quantitative descriptive methods include income analysis, welfare level analysis according to BPS and Sayogyo, and using a binary logit model. The results show that the source of household income of cassava farmers is increasingly diverse and leads to off and non-farm activities. Revenue from cassava farming has decreased but is still dominant. Based on BPS and Sayogyo criteria, most cassava farming households are in a decent and prosperous life group. The factors that influence the level of welfare of cassava farmers are the amount of work, cassava farming experience, and household income.
\end{abstract}

Keywords: income, ubikayu, welfare

\begin{abstract}
ABSTRAK
Penelitian ini bertujuan untuk (1) menganalisis tingkat pendapatan dan kesejahteraan rumah tangga petani ubikayu, dan (2) menganalisis faktor faktor yang mempengaruhi tingkat kesejahteraan rumah tangga petani ubikayu. Penelitian dilaksanakan di Desa Gunung Agung Kecamatan Terusan Nunyai Kabupaten Lampung Tengah dengan metode survey. Petani sampel berjumlah 78 responden yang diambil secara stratified proporsional simple random sampling. Analisis data menggunakan metode deskriptif kuantitatif meliputi analisis partial budget, analisis tingkat kesejahteraan menurut BPS, Sayogyo menggunakan model binary logit. Hasil penelitian menunjukkan bahwa sumber pendapatan rumah tangga petani ubikayu semakin beragam dan mengarah ke aktivitas off dan non farm. Pendapatan dari usahatani ubikayu pangsanya menurun namun masih dominan. Berdasarkan kriteria BPS dan Sayogyo sebagian besar rumah tangga petani ubikayu berada pada golongan hidup layak dan sejahtera. Faktor-faktor yang berpengaruh terhadap tingkat kesejahteraan rumah tangga petani ubikayu adalah jumlah pekerjaan, pengalaman berusahatani ubikayu, dan pendapatan rumah tangga.
\end{abstract}

Kata kunci: pendapatan, tingkat kesejahteraan, ubikayu

\section{PENDAHULUAN}

Salah satu tujuan pembangunan pertanian adalah untuk meningkatkan pendapatan dan kesejahteraan masyarakat (petani). Sejak Reformasi 1997 sampai 2015, Pertanian masih menjadi sektor yang memiliki pendapatan per kapita paling rendah dibandingkan sektor lainnya. Tahun 2014, produktivitas per kapita sektor pertanian hanya 0,35 dari produktivitas perkapita nasional, sedangkan untuk produktivitas perkapita pada sektor pertambangan mencapai 5,15 atau 14,5 kali lipat dibandingkan sektor pertanian. Kondisi seperti ini dikhawatirkan akan menyebabkan terjadinya proses pemiskinan dan eksploitasi sumberdaya manusia pada sektor pertanian (BPS, 
2015). Bukti transformasi struktural pertanian dan kemiskinan di sektor pertanian adalah semakin menurunnya jumlah petani pemilik lahan dan meningkatnya buruh pertanian di Indonesia dalam rentang waktu 2004 ke 2014. Pada tahun 2004 jumlah petani pemilik lahan adalah 60,34 persen turun menjadi 36,76 persen pada 2014, sedangkan buruh tani dari angka 24,77 persen menjadi 49,03 persen. Hal ini menandakan bahwa sektor pertanian tidak menguntungkan dan tidak mampu memenuhi kebutuhan rumah tangga karena semakin banyak petani yang tidak memiliki lahan kemudian menjadi buruh tani.

Perubahan tenaga kerja dari usahatani menjadi buruh tani terjadi karena adanya ketimpangan pendapatan. Secara teoritis tingkat ketimpangan distribusi pendapatan berhubungan dengan perubahan struktur ekonomi. Makki (1994) menyatakan bahwa perubahan struktur ekonomi akan berdampak terhadap distribusi pendapatan, karena belum menunjukkan adanya keseimbangan dengan penyerapan tenaga kerja, sehingga terjadi paradok dalam perekonomian dimana tingkat ketimpangan cenderung meningkat. Kahya (2012) juga menyatakan bahwa perubahan struktur ekonomi akan memiliki dampak terhadap ketimpangan distribusi pendapatan, yaitu dampak negatif dan positif, artinya perubahan struktur ekonomi dapat meningkatkan dan menurunkan tingkat ketimpangan distribusi pendapatan. Perubahan struktur ekonomi merupakan suatu proses terjadinya pergeseran peran sektor-sektor dalam struktur perekonomian, dari sektor primer ke sektor sekunder kemudian ke sektor tersier (Chenery dan Syrquin, 1975). Fenomena ini juga dialami oleh petani ubikayu di Provinsi Lampung.

Provinsi Lampung adalah sentra produksi ubikayu terbesar di Indonesia. Pada tingkat provinsi, Kabupaten Lampung Tengah merupakan sentra produksi ubikayu utama di Provinsi Lampung. Pada tahun 2016 luas panen ubikayu. Kabupaten Lampung Tengah 68.720 ha dengan produksi ubikayu sebesar 1.730.156 ton. Dengan produksi tersebut, menjadikan Kabupaten Lampung Tengah bukan hanya kabupaten dengan produksi terbesar di Lampung tetapi juga di Indonesia. Pada Tahun 2018 produksi aktual rata-rata ubikayu berkisar 23,5 ton per ha, masih tergolong rendah jika dibandingkan dengan produksi potensial 30-35 ton per ha.

Meskipun secara makro usahatani ubikayu terlihat menguntungkan, tetapi kenyataannya pada usahatani ubikayu menghadapi banyak permasalahan seperti: keterbatasan penguasaan teknologi produksi, keterbatasan modal usahatani, manajemen budidaya yang belum efisien, tidak adanya jaminan pasar yang menyebabkan rendahnya harga yang diterima petani karena posisi tawar (bargaining position) petani terhadap pabrik sangat rendah, semakin rendahnya tingkat kesuburan tanah yang menyebabkan produktivitas ubikayu semakin rendah dan semakin besar kebutuhan input dan biaya yang dikeluarkan dalam usahatani ubikayu.

Banyaknya kendala yang dihadapi usahatani menyebabkan pendapatan dan kesejahteraan petani ubikayu menjadi rendah dan peluang transformasi ke petani nonubikayu, atau bekerja di sektor non pertanian (off farm) akan semakin besar dan jika hal ini dibiarkan akan mengancam keberlanjutan usahatani ubikayu dimasa yang akan datang. Untuk mengatasi rendahnya pendapatan keluarga, nampaknya sektor pertanian masih dapat menjadi andalan yaitu melalui sistem agribisnis, terutama peningkatan produktivitas usahatani, pemasaran dan pengolahan produk bahan baku menjadi bahan jadi. Aktivitas-aktivitas ini sama saja dengan upaya atau program dari Revitalisasi Pertanian yaitu peningkatan ketahanan pangan, pengembangan agribisnis dan peningkatan kesejahteraan petani. Peningkatan produktivitas terutama dapat dilakukan melalui intensitas penggunaan tenagakerja. Pemasaran yang efisien berwawasan kepada konsumen (Consumer's market) dengan pengolahan produk, akan meningkatkan permintaan atau memperluas pasar. Pengolahan produk dari bahan baku menjadi bahan setengah jadi atau bahan jadi, akan memberikan nilai tambah petani ubikayu. Semua aktivitas ini diharap- 
kan dapat menyerap tenaga kerja keluarga yang ada dan akhirnya akan meningkatkan pendapatan atau kesejahteraan keluarga (Asmarantaka, 2007). Berdasarkan hal di atas maka tujuan penelitian ini adalah untuk menganalisis tingkat pendapatan dan kesejahteraan rumah tangga petani ubikayu serta faktor-faktor yang mempengaruhi tingkat kesejahteraan.

\section{METODE}

\section{PENGUMPULAN DATA DAN ANALISIS}

Penelitian dilaksanakan pada bulan Mei sampai Oktober 2019. Pemilihan lokasi dilakukan secara sengaja dengan pertimbangan Desa Gunung Agung Kecamatan Terusan Nunyai Kabupaten Lampung Tengah, merupakan sentra produksi ubikayu di Provinsi Lampung. Petani sampel berjumlah 78 orang yang diambil secara stratified proporsional simple random sampling. Analisis data menggunakan metode deskriptif kuantitatif meliputi analisis pendapatan rumah tangga petani dan analisis tingkat kesejahteraan menurut BPS dan Sayogyo.

Pendapatan diperoleh dengan menghitung selisih antara total penerimaan dari hasil usaha dengan total biaya produksi yang dikeluarkan petani selama satu tahun (Hastuti, dkk. 2008). Pendapatan rumah tangga merupakan pendapatan yang berasal dari usahatani (on farm), non usahatani (off farm), dan dari luar usaha pertanian (non farm). Pendapatan rumah tangga petani ubikayu dapat dihitung dengan rumus:

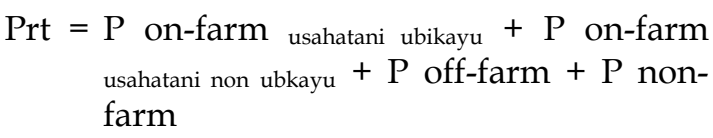
usahatani non ubkayu $+\mathrm{P}$ off-farm $+\mathrm{P}$ nonfarm

Keterangan :

Prt = Pendapatan rumah tangga petani ubikayu per tahun

Pon-farm usahatani ubikayu = Pendapatan dari usaha-tani ubikayu

Pon-farm usahatani non ubikayu = Pendapatan usahatani selain ubikayu
P off-farm = Pendapatan non usahatani ubikayu

P non-farm $=$ Pendapatan dari luar pertanian

Tingkat kesejahteraan petani ubikayu ditentukan indikator Badan Pusat Statistik (2014) yaitu dengan melihat informasi tentang kependudukan, kesehatan dan gizi, pendidikan, ketenagakerjaan, pola konsumsi, atau pegeluaran rumah tangga, perumahan dan lingkungan serta kondisi sosial lainnya. Mengukur tingkat kesejahteraan rumah tangga dengan menggunakan dua klasifikasi yaitu rumah tangga dengan kategori sejahtera dan belum sejahtera. Pengukuran masing-masing klasifikasi dengan mengurangkan jumlah skor tertinggi dengan jumlah skor terendah. Hasil pengurangan dibagi dengan jumlah klasifikasi atau indikator yang digunakan. Rumus penentuan range skor adalah:

$$
\mathrm{RS}=\frac{\mathrm{SkT}-\mathrm{SkR}}{\mathrm{JK} 1}
$$

Keterangan :

RS = Range Skor

SkT $=$ Skor tertinggi $(7 \times 3=21)$

SkR $=$ Skor terendah $(7 \times 1=7)$

7 = Jumlah indikator kesejahteraan BPS (kependudukan, kesehatan dan gizi, pendidikan, ketenagakerjaan, pola konsumsi atau pengeluaran rumah tangga, perumahan dan lingkungan, dan sosial lainnya).

3 = Skor tertinggi dalam indikator BPS (baik)

1 = Skor terendah dalam indikator BPS (kurang)

JK1 = Jumlah klasifikasi yang digunakan

Berdasarkan rumus tersebut diperoleh range skor (RS) sama dengan tujuh, sehingga tingkat kesejahteraan rumah tangga petani ubikayu adalah :

(1) Jika skor antara 7 - 14 berarti rumah tangga petani belum sejahtera.

(2) Jika skor antara 15 - 21 berarti rumah tangga petani sejahtera.

Pengukuran tingkat kesejahteraan Sayogyo (1997) menjelaskan bahwa pengeluaran rumah tangga merupakan total 
pengeluaran rumah tangga petani baik pengeluaran untuk pangan maupun non pangan serta pengeluaran lainnya. Persentase pengeluaran pangan pada tingkat rumah tangga adalah rasio pengeluaran pangan terhadap total pengeluaran rumah tangga. Pengeluaran rumah tangga per kapita per tahun ini kemudian dibagi dengan harga beras per kilogram untuk mengukur tingkat kesejahteraan rumah tangga.

Menurut Sayogyo (1997), peringkat kemiskinan didasarkan pada besarnya pengeluaran per kapita per tahun yang diukur dengan setara harga beras setempat untuk daerah pedesaan adalah:

\section{Hidup layak}

apabila pengeluaran/kapita/tahun lebih tinggi dari $960 \mathrm{~kg}$ setara nilai beras/tahun.

2. Cukup

apabila pengeluaran/kapita/tahun antara 481-960 kg setara nilai beras/tahun.

3. Nyaris miskin apabila pengeluaran/ kapita/tahun antara 321-480 kg setara nilai beras/tahun.

4. Miskin

apabila pengeluaran/kapita/tahun lebih rendah dari nilai tukar $320 \mathrm{~kg}$ beras.

5. Miskin Sekali

apabila pengeluaran/kapita/tahun lebih rendah dari nilai tukar $240 \mathrm{~kg}$ beras.

6. Paling Miskin

apabila pengeluaran/kapita/tahun lebih rendah dari nilai tukar $180 \mathrm{~kg}$.

Untuk mengetahui faktor-faktor yang mempengaruhi tingkat kesejahteraan rumah tangga petani ubikayu digunakan model binary logit. Model logit adalah model probabilitas logistik untuk menjelaskan respon kualitatif variabel dependen. Bentuk persamaan model logit yang digunakan adalah sebagai berikut:

$$
\begin{aligned}
\ln (\mathrm{Pi} / 1-\mathrm{Pi})= & \mathrm{Zi}=\beta_{0}+\beta_{1} \mathrm{X}_{1}+\beta_{2} \mathrm{X}_{2}+\beta_{3} \mathrm{X}_{3}+\beta_{4} \mathrm{X}_{4} \\
& +\beta_{5} \mathrm{X}_{5}+\beta_{6} \mathrm{X}_{6}
\end{aligned}
$$

Keterangan : Zi merupakan peluang petani tidak sejahtera $(0)$, petani sejahtera $(1), \beta_{0}$ konstanta $\beta_{1}, \beta_{2}, \beta_{3}, \beta_{4}, \beta_{5}, \beta_{6}$, koefisien regresi, $\left(X_{1}\right)$ jumlah anggota keluarga, $\left(X_{2}\right)$ pen- didikan, $\left(\mathrm{X}_{3}\right)$ pendapatan keluarga, $\left(\mathrm{X}_{4}\right)$ jumlah pekerjaan, $\left(\mathrm{X}_{5}\right)$ pengalaman usahatani dan $\left(X_{6}\right)$ luas lahan. Iskandar (2007) menyebutkan bahwa faktor yang mempengaruhi tingkat kesejahteraan yaitu pendapatan, pendidikan, pekerjaan, dan jumlah anggota keluarga. Sementara itu, Ndakularak, Setiawina, dan Djayastra (2014) pada penelitiannya menyebutkan bahwa faktor-faktor yang mempengaruhi tingkat kesejahteraan yaitu pengeluaran nonpangan rumah tangga.

\section{HASIL DAN PEMBAHASAN}

Rata-rata umur petani responden di Desa Gunung Agung 49 tahun, sebagian besar $(92 \%)$ petani responden tergolong ke dalam usia produktif (40 sampai 50 tahun). Ini menunjukkan bahwa responden berada di dalam usia yang aktif secara ekonomi dan produktif. Ini adalah konsisten dengan hasil penelitian Mukhtar (2012) yang mayoritas dari para petani berada dalam kurung usia 41 dan 50 tahun. Sebagian besar petani memiliki tingkat pendidikan tamat SD. Hal ini berarti bahwa sebagian besar petani mampu menulis, membaca dan berhitung sebagai modal bagi petani untuk mengelola usahanya. Dengan demikian diharapkan petani mampu mengakses sumber-sumber informasi baik tentang teknologi maupun tentang keragaan pasar ubikayu guna pengambilan keputusan dalam produksi dan konsumsi. Rata-rata jumlah tanggungan keluarga 4 orang. Jumlah tanggungan keluarga sangat mempengaruhi proporsi pengeluaran rumah tangga baik untuk pangan maupun non pangan, sehingga tanggungan keluarga dapat digunakan sebagai alat ukur dalam menentukan tingkat kesejahteraan rumah tangga petani responden.

Beberapa petani ubikayu mempunyai pekerjaan sampingan di luar pekerjaan utamanya sebagai petani ubikayu untuk mencukupi kebutuhan dan menambah pendapatan rumah tangga. Jenis pekerjaannya pun mulai dari pekerjaan tambahan yang masih dalam kegiatan pertanian (luar ubikayu) maupun di luar kegiatan pertanian. Sebagian besar petani 
(71,79\%) memiliki luas lahan garapan kurang dari 1,5 ha (strata sempit). Semakin kecil luas lahan garapan petani ubikayu, maka semakin kecil produksi yang diperoleh sehingga akan berdampak terhadap tingkat pendapatan yang diterima petani ubikayu.

Penurunan jumlah luasan lahan garapan akan berdampak pada kuantitas hasil produksi pertanian (Ginting, 2010 dan Yunus, 2008). Sebagian responden $(28,21 \%)$ petani ubikayu memiliki pengalaman berusahatani rata-rata selama 16 tahun. Hal ini menunjukkan bahwa responden cukup berpengalaman dalam mengelola usahatani ubikayunya. Pengalaman berusahatani dapat memberikan dampak terhadap cara pengelolaan usahatani dan tingkat keberhasilannya.

\section{TINGKAT PENDAPATAN RUMAH TANGGA PETANI UBIKAYU}

Tingkat pendapatan rumah tangga berpengaruh terhadap tingkat kesejahteraan rumah tangga. Jika pendapatan rumah tangga bertambah, maka pengeluaran rumah tangga juga akan bertambah sebaliknya, sehingga rumah tangga dengan pendapatan yang lebih besar cenderung lebih sejahtera dibandingkan dengan rumah tangga yang berpendapatan kecil. Sumber pendapatan rumah tangga berasal dari pendapatan usahatani meliputi kegiatan budidaya (on-farm), kegiatan di luar budidaya (off-farm), kegiatan di luar sektor pertanian (non-farm). Tiap sektor pendapatan memberikan kontribusi yang berbeda terhadap total pendapatan rumah tangga petani ubikayu. Masing-masing pendapatan mempunyai peranan yang dapat menggambarkan kemampuan daya dukung sumber daya alam dan manusia.

Sumber utama pendapatan rumah tangga petani ubikayu berasal dari kegiatan usahatani ubikayu. Analisis Pendapatan Usahatani Ubikayu di Desa Gunung Agung Kecamatan Terusan Nunyai dapat dilihat pada Tabel 1.
Tabel 1. Analisis Pendapatan Usahatani Ubikayu di Desa Gunung Agung Kecamatan Terusan Nunyai Kabupaten Lampung Tengah.

\begin{tabular}{|c|c|c|c|}
\hline \multirow[b]{2}{*}{ Uraian } & \multicolumn{3}{|c|}{ Usahatani per 1 ha } \\
\hline & Jumlah & $\begin{array}{c}\text { Harga } \\
\text { (Rp) }\end{array}$ & Nilai (Rp) \\
\hline Produksi & $25,453.7$ & 988,71 & $25.166 .337,61$ \\
\hline \multicolumn{4}{|l|}{ Biaya Produksi } \\
\hline Biaya Tunai & & & $9.041 .015,93$ \\
\hline Bibit & 109,54 & 7.050 & $772.286,30$ \\
\hline Urea & 145,81 & 1.900 & $277.035,00$ \\
\hline Phonska & 50,37 & $3.273,08$ & $164.852,78$ \\
\hline Tsp & 97,43 & 5.900 & $574.811,76$ \\
\hline $\mathrm{Kcl}$ & 122,61 & $5.914,10$ & $725.121,45$ \\
\hline Pestisida & 8,7 & $58.33,65$ & $508.372,77$ \\
\hline \multicolumn{4}{|l|}{ TK Luar } \\
\hline Keluarga & 69,3 & $61.974,67$ & $4.294 .844,63$ \\
\hline Pajak & & & $65.932,79$ \\
\hline Biaya Angkut & & & $1.657 .758,445$ \\
\hline \multicolumn{4}{|l|}{ Biaya } \\
\hline Diperhitungkan & & & $3.402 .924,67$ \\
\hline \multicolumn{4}{|l|}{ TK Dalam } \\
\hline Keluarga & 4,8 & $61.97,67$ & $296.615,38$ \\
\hline Penyusutan Alat & & & $106.309,29$ \\
\hline Sewa Lahan & & & $3.000 .000,00$ \\
\hline Total Biaya & & & $12.443 .940,60$ \\
\hline \multicolumn{4}{|l|}{ Pendapatan } \\
\hline Tunai & & & $16.125 .321,68$ \\
\hline \multicolumn{4}{|l|}{ Pendapatan } \\
\hline Total & & & $12.722 .397,01$ \\
\hline R/C Tunai & & & 2,78 \\
\hline R/C Total & & & 2,02 \\
\hline
\end{tabular}

Sumber : Data Primer diolah, 2019

Tabel 1 menunjukkan rata-rata produktivitas ubikayu sebesar $25.453,70 \mathrm{~kg} / \mathrm{ha}$ dengan harga jual sebesar Rp 988,71/kg. Berdasarkan hasil tersebut, maka diperoleh penerimaan sebesar Rp 25.166.337,61/ha. Struktur ongkos produksi ubikayu terdiri dari biaya tunai yang terdiri dari biaya bibit, pupuk urea, Phonska, Tsp, Kcl, Pestisida, tenaga kerja luar keluarga, pajak dan biaya angkut. Biaya diperhitungkan terdiri dari biaya tenaga kerja luar keluarga, penyusutan alat dan sewa lahan. Total biaya yang harus dikeluarkan untuk usahatani ubikayu sebesar Rp 12,443,940.60/ha. R/C Rasio atas biaya tunai dan R/C Rasio atas biaya total diperoleh 
sebesar 2,78 dan 2,02 nilai ini lebih dari 1 yang artinya usahatani ubikayu menguntungkan dan layak untuk diusahakan. Penelitian Zakaria, W.A (2018) tentang Model Kelembagaan Kemitraan Agribisnis Ubikayu di Provinsi Lampung menunjukkan bahwa usahatani petani ubikayu yang melakukan kemitraan dan petani ubikayu yang tidak melakukan kemitraan diperoleh $\mathrm{R} / \mathrm{C}$ rasio lebih dari satu sehingga usahatani ubikayu masih menguntungkan dan layak untuk diusahakan. Hal ini berarti bahwa perdapatan dari usahatani ubikayu masih memegang peranan penting dalam menjaga keberlangsungan hidup rumah tangga petani ubikayu. Rata-rata pendapatan rumah tangga petani ubikayu dapat dilihat pada Tabel 2.

Tabel 2. Rata-Rata Pendapatan Rumah Tangga Petani Ubikayu Di Desa Gunung Agung Kecamatan Terusan Nunyai Kabupaten Lampung Tengah

\begin{tabular}{lcc}
\hline $\begin{array}{c}\text { Sumber } \\
\text { Pendapatan } \\
\text { Rumah } \\
\text { Tangga }\end{array}$ & $\begin{array}{c}\text { Pendapatan } \\
\text { (Rp) }\end{array}$ & $\begin{array}{c}\text { Persentase } \\
\mathbf{( \% )}\end{array}$ \\
\hline $\begin{array}{l}\text { Pon-farm } \\
\text { usahatani }\end{array}$ & & \\
ubikayu & $25.166 .337,61$ & 43,44 \\
Pon-farm & & \\
usahatani non & & \\
ubikayu & $22.666 .029,33$ & 39,10 \\
P_off farm & $4.933 .846,15$ & 8,51 \\
P_non farm & $5.190 .000,00$ & 8,95 \\
\hline Jumlah & $57.956 .213,09$ & 100,00 \\
\hline
\end{tabular}

Penelitian Iqbal, dkk (2014) menunjukkan bahwa kontribusi terbesar dari pendapatan rumah tangga petani ubikayu di Kecamatan Sukadana Lampung Timur adalah dari pendapatan usahatani ubikayu sebesar 90,20\%, pendapatan off farm, 1,2 \%, dan non farm $6,27 \%$. Petani masih mengandalkan sektor pertanian sebagai mata pencaharian utama mereka di tengah maraknya pergeseran tenaga kerja dari sektor pertanian ke sektor lainnya.

Sementara itu, sumber pendapatan rumah tangga terkecil berasal dari kegiatan usaha di luar kegiatan pertanian (off-farm) yaitu sebesar $8,51 \%$. Ini berarti bahwa transformasi ekonomi di perdesaan masih tetap menempatkan sektor pertanian sebagai sektor yang memegang peranan penting, baik dalam menyerap tenaga kerja maupun dalam menyumbang pendapatan. Tingginya kontribusi sektor pertanian dalam pendapatan rumah tangga konsisten dengan hasil berbagai penelitian sebelumnya. Saliem et al. (2005), Racman et al. (2004) dalam Saliem et al. (2005), menyatakan bahwa sektor pertanian merupakan sumber utama pendapatan rumah tangga pertanian. Marisa dan Hutabarat (1988); dan Susilowati, et al. (2002), juga menyatakan bahwa pendapatan utama rumah tangga pertanian berasal dari sektor pertanian.

Tingkat pendapatan rumah tangga petani ubikayu di Desa Gunung Agung Kecamatan Terusan Nunyai Kabupaten Lampung Tengah termasuk ke dalam golongan pendapatan tinggi, hal ini karena rata-rata perhitungan pendapatan perbulan rumah tangga petani ubikayu sebesar Rp4.826.543,47. Menurut Badan Pusat Statistik (2008), apabila pendapatan rata-rata perbulan antara Rp2.500.000,00 hingga Rp5.000.000,00 maka pendapatan tersebut tergolong ke dalam pendapatan yang tinggi.

\section{ANALISIS TINGKAT KESEJAHTERAAN RUMAH TANGGA PETANI UBIKAYU BERDASARKAN KRITERIA BPS DAN SAYOGYO}

Menurut BPS (2014), tingkat kesejahteraan rumah tangga ditentukan oleh beberapa indikator yaitu kependudukan, kesehatan dan gizi, pendidikan, ketenagakerjaan, pola konsumsi, perumahan, lingkungan, sosial dan lain-lain. Berdasarkan indikator tersebut tingkat ksejahteraan rumah tangga petani ubikayu di Desa Gunung Agung Kecamatan Terusan Nunyai menurut BPS dapat dilihat pada Tabel 3.

Tabel 3 menunjukkan terdapat 59 rumah tangga petani ubikayu yang tergolong ke dalam kategori sejahtera, sementara sisanya sebesar 19 rumah tangga petani ubikayu 
tergolong dalam kategori belum sejahtera $(24,36 \%)$ karena indikator pendidikan rendah. Penelitian Rambe dkk (2008), pendidikan keluarga merupakan salah satu faktor yang mempengaruhi tingkat kesejahteraan keluarga semakin tinggi pendidikan semakin besar peluang keluarga untuk sejahtera.

Tabel 3. Tingkat Kesejahteraan Petani Ubikayu Berdasarkan Kriteria BPS

\begin{tabular}{lccc}
\hline \multirow{2}{*}{ Kategori } & \multicolumn{3}{c}{ Petani Ubikayu } \\
\cline { 2 - 4 } & Skor & $\begin{array}{c}\text { Jumlah } \\
\text { Orang }\end{array}$ & $\begin{array}{c}\text { Persen } \\
\mathbf{( \% )}\end{array}$ \\
\hline Belum Sejahtera & $13-14$ & 19 & 24,36 \\
Sejahtera & $15-17$ & 59 & 75,64 \\
\hline Jumlah & & $\mathbf{7 8}$ & $\mathbf{1 0 0}$ \\
\hline Sumber: &
\end{tabular}

Sumber : Data Primer diolah, 2019

Penelitian Iqbal (2014) menunjukkan bahwa sebagian besar petani ubikayu di Kecamatan Sukadana Kabupaten Lampung Timur tergolong sejahtera. Penelitian Rizal 2018, berdasarkan 11 indikator kesejahteraan BPS menunjukkan bahwa seluruh rumah tangga pembudidaya ikan termasuk dalam golongan sejahtera.

Tingkat kesejahteraan petani ubikayu juga diukur dengan kriteria Sayogyo yaitu dengan mengkonversikan total pengeluaran rumah tangga per kapita per tahun dengan harga beras yang berlaku. Harga beras yang digunakan adalah Rp11.647,00 per kg yang merupakan rata-rata harga beras yang dikonsumsi responden.

Pada penelitian ini, aspek pengeluaran pangan meliputi pangan pokok, lauk pauk, sayuran, buah-buahan, bumbu-bumbu, minuman, makanan ringan, dan lainnya. Adapun aspek pengeluaran nonpangan meliputi kesehatan, pendidikan, pakaian, transportasi, listrik, bahan bakar, social, perabotan rumah tangga, PBB, rokok, komunikasi dan lainnya. Adapun pengeluaran rata-rata pertahun rumah tangga petani ubikayu di Desa Gunung Agung Kecamatan Terusan Nunyai Kabupaten Lampung Tengah disajikkan pada Tabel 4.
Tabel 4. Rata-rata Total Pengeluaran Rumahtangga Petani Ubikayu di Kecamatan Terusan Nunyai Kabupaten Lampung Tengah, tahun 2019

\begin{tabular}{|c|c|c|}
\hline \multirow[b]{2}{*}{ Jenis Pengeluaran } & \multicolumn{2}{|c|}{ Petani Ubikayu } \\
\hline & $\begin{array}{c}\text { Rata-rata } \\
\text { Pengeluaran } \\
\text { RT/Th }\end{array}$ & $\begin{array}{c}\text { Pangsa } \\
(\%)\end{array}$ \\
\hline \multicolumn{3}{|l|}{ Pangan } \\
\hline Beras & $3.126 .538,46$ & 15,67 \\
\hline Tiwul & $10.290,91$ & 0,05 \\
\hline Lauk Pauk & $4.545 .384,62$ & 22,78 \\
\hline Sayuran & $1.882 .307,69$ & 9,43 \\
\hline Buah-buahan & $763.436,07$ & 3,83 \\
\hline Bumbu-bumbu & $2.825 .384,62$ & 14,16 \\
\hline Minuman & $1.712 .769,23$ & 8,58 \\
\hline Makanan Ringan & $1.276 .285,71$ & 6,39 \\
\hline \multicolumn{3}{|l|}{ Total Pengeluaran } \\
\hline Pangan & 16.142.397,31 & 35,49 \\
\hline \multicolumn{3}{|l|}{ Non Pangan } \\
\hline Kesehatan & $1.526 .230,31$ & 5,98 \\
\hline Pendidikan & 4.191.118,18 & 16,42 \\
\hline Pakaian & $4.523 .738,10$ & 17,72 \\
\hline Transportasi & $2.115 .501,60$ & 8,29 \\
\hline Listrik & $1.989 .076,92$ & 7,79 \\
\hline Bahan Bakar & 3.952.330,83 & 15,48 \\
\hline Sosial & $990.247,71$ & 3,88 \\
\hline Perabotan RT & $1.918 .623,38$ & 7,52 \\
\hline РBB & $462.898,16$ & 1,81 \\
\hline Rokok & $3.815 .238,10$ & 13,00 \\
\hline Komunikasi & $1.180 .628,57$ & 4,62 \\
\hline Lainnya & $2.677 .083,67$ & 10,49 \\
\hline \multicolumn{3}{|l|}{ Total Pengeluaran } \\
\hline Non Pangan & 29.342.715,53 & 64,51 \\
\hline \multicolumn{3}{|l|}{ Total Pengeluaran } \\
\hline Rumah Tangga & $45.485 .112,84$ & 100,00 \\
\hline
\end{tabular}

Sumber : Data Primer diolah, 2019

Tabel 4 menunjukkan pengeluaran total rumah tangga petani ubikayu di Desa Gunung Agung Kecamatan Terusan Nunyai Kabupaten Lampung Tengah sebesar Rp45.485.112,83 pertahun. Pangsa pengeluaran non pangan sebesar 64,51\% lebih besar dibandingkan dengan pangan 34,49\%.

Tingginya pengeluaran non pangan disebabkan oleh berbagai hal seperti semakin banyak jumlah anggota keluarga, tingkat pendidikan keluarga, mobilitas anggota keluarga dan untuk rokok. 
Adapun sisa pendapatan yang ditabung sebesar Rp12.433.399,82. Tabungan ini bermanfaat bagi petani responden untuk memenuhi kebutuhan yang mendesak seperti biaya untuk berobat dan kebutuhan lainnya.

Rumah tangga petani ubikayu di Kecamatan Terusan Nunyai terbagi menjadi tiga golongan yaitu nyaris miskin, cukup, dan hidup layak. Sebaran petani ubikayu menurut tingkat pengeluaran dan golongan kesejahteraan menurut Sayogyo disajikan pada Gambar 1.

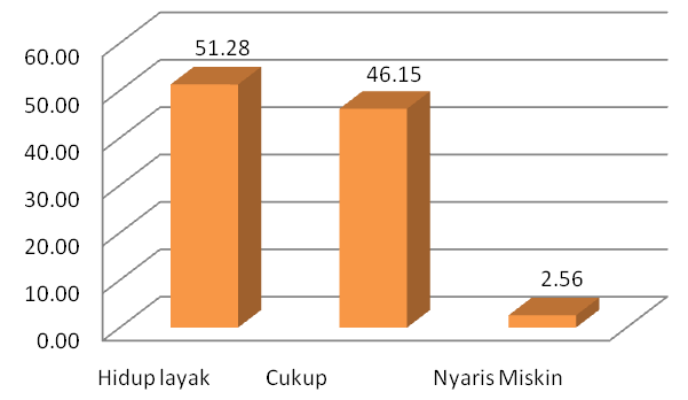

Gambar 1. Kriteria Kesejahteraan Sayogyo Sumber : Data Primer diolah, 2019

Gambar 1 menunjukkan bahwa sebagian besar rumah tangga petani ubikayu berada pada golongan hidup layak $51,28 \%$, golongan rumah tangga cukup $46,15 \%$, dan rumah tangga petani nyaris miskin sebesar 2,56\%. Hal ini terjadi karena adanya mata pencarian lain selain sebagai petani ubikayu. Berdasarkan kriteria Sayogyo ini berarti rumah tangga petani ubikayu di Desa Gunung Agung termasuk golongan sejahtera. Hal ini sejalan dengan penelitian Syakina, dkk (2019) yang berjudul analisis pendapatan, kesejahteraan rumah tangga dan strategi pengembangan usaha budidaya lele menunjukkan analisis tingkat kesejahteraan dengan kriteria Sajogyo diketahui bahwa 20 persen rumah tangga pembudidaya lele berada dalam golongan nyaris miskin, 50 persen rumah tangga di golongan cukup, dan 30 persen rumah tangga di golongan hidup layak.

\section{FAKTOR-FAKTOR YANG MEMPENGARUHI TINGKAT KESEJAHTERAAN RUMAH TANGGA PETANI UBIKAYU}

Hasil pengujian dengan analisis binary logit menunjukkan bahwa faktor-faktor yang mempengaruhi tingkat kesejahteraan petani ubikayu adalah jumlah pekerjaan, pengalaman berusahatani ubikayu, dan pendapatan, tertera pada Tabel 5. Nilai statistik masingmasing sebesar 3,31659; 1,847161 dan 2,26337 dengan probabilitas 0,0015; 0.0069 dan 0,0000 menunjukkan bahwa variabel jumlah pekerjaan, pengalaman usahatani dan pendapatan berpengaruh signifikan terhadap tingkat kesejahteraan. Nilai odds ratio variabel jumlah pekerjaan sebesar 1,69 berarti semakin beragam jenis pekerjaan yang dimiliki maka tingkat kesejahteraan petani ubikayu meningkat sebesar 1,69 kali.

Nilai odds ratio variabel pengalaman usahatani sebesar 1,17 yang berarti semakin lama pengalaman berusahatani ubikayu akan semakin meningkat peluang kesejahteraan rumah tangga petani ubikayu sebesar 1,17 kali. Pendapatan dengan nilai odd ratio 2,26 menunjukan setiap kenaikan pendapatan

Tabel 5. Hasil Analisis Regresi Binary Logit Faktor-faktor yang Mempengaruhi Tingkat Kesejahteraan Petani Ubikayu di Provinsi Lampung Berdasarkan Kriteria Sayogyo dan BPS

\begin{tabular}{llccccc}
\hline \multicolumn{1}{c}{ Variabel } & Coefficient & Std. Error & z-Statistic & Prob. & Odd rasio \\
\hline Sayogyo & Konstanta & 14,2503 & 1,076592 & 13,23649 & 0,0000 & 1544637,7 \\
& Jumlah pekerjaan & $0,526626^{* *}$ & 0,158785 & 3,31659 & 0,0015 & 1,6932 \\
& Pengalaman & $0,155911^{*}$ & 0,084406 & 1,847161 & 0,0069 & 1,1687 \\
\hline \multirow{2}{*}{ BPS } & Konstanta & 3,20362 & 0,652927 & 4,906562 & 0,0000 & 24,6216 \\
& Pendapatan & $0,816984^{* *}$ & 0,036664 & 22,28326 & 0,0000 & 2,26337 \\
\hline
\end{tabular}

Keterangan : ** = signifikan pada tingkat kepercayaan $99 \%$

Sumber : Data Primer diolah, 2019 
maka kesejahteraan petani ubikayu akan meningkat sebesar 2,26 kali.

Igweoscar (2014), meneliti tentang Pengaruh Kontrak Pertanian terhadap Produktivitas dan Kesejahteraan Petani Berbasis Ubikayu di Nigeria Tenggara menunjukkan bahwa faktor-faktor signifikan yang mempengaruhi kesejahteraan petani ubikayu adalah pendidikan, total pendapatan rumah tangga, kepemilikan tanah, pengalaman berusahatani, dan biaya produksi.

Di daerah penelitian, rumah tangga petani responden memiliki jumlah pekerjaan yang beragam. Di samping mengusahakan tanaman ubikayu, petani responden juga mengusahakan tanaman lainnya guna meningkatkan pendapatan rumah tangga. Selain itu terdapat juga rumah tangga petani responden yang memiliki pekerjaan lain baik di luar kegiatan budidaya maupun di luar pertanian. Peningkatan jumlah pekerjaan petani ubikayu terjadi karena adanya pembangunan pabrik tapioka, pabrik nanas dan pabrik gula dilokasi penelitian. Kondisi ini menyebabkan multiflier effect yang sangat besar terdapat perkembangan ekonomi wilayah, peningkatan lapangan pekerjaan diluar ubikayu.

Di Desa Gunung Agung Kecamatan Terusan Nunyai, pendapatan rumah tangga petani berasal dari usahatani tebu, ternak ayam, kambing, sapi, buruh tani, karyawan, supir, kuli, pedagang. Rumah tangga petani yang memiliki keberagaman usaha akan memiliki pendapatan yang lebih tinggi dibandingkan petani yang hanya mengandalkan pendapatannya hanya dari usahatani ubikayu.

Pengalaman berusahatani ubikayu juga mempengaruhi tingkat kesejahteraan. Responden memiliki pengalaman berusahatani ubikayu selama 21 sampai dengan 30 tahun. Semakin berpengalaman maka petani akan memiliki keterampilan dan pengetahuan yang lebih luas serta lebih baik untuk menghadapi kendala-kendala usahatani. Selain itu semakin lama pengalaman akan semakin tinggi produktivitas dan pendapatan sehingga kesejahteraan juga akan meningkat. mengelola usahatani yang baik sangat tergantung dari pengalaman petani karena pengalaman merupakan salah satu sarana tidak langsung dalam meningkatkan taraf hidup para petani. Semakin lama petani berusahatani diharapkan petani semakin mampu mengelola usahatani dengan baik sehingga pendapatan petani meningkat (Mwaura, 2014).

Pendapatan riil petani sangat dipengaruhi oleh keragaman ekonomi rumah tangga petani. Ekonomi rumah tangga yang beragam menyebabkan adanya variasi atau perbedaan dalam pencapaian tingkat kesejahteraan (Naidu, 2013).

\section{KESIMPULAN DAN SARAN}

\section{KESIMPULAN}

1. Pendapatan rumah tangga petani ubikayu semakin beragam dan mulai mengarah ke sumber pendapatan dari kegiatan non dan off farm. Namun demikian pendapatan usahatani ubikayu masih memiliki pangsa yang dominan dalam pendapatan rumah tangga petani ubikayu. Semakin beragam mata pencarian petani ubikayu maka semakin tinggi tingkat kesejahteraan rumah tangga. Berdasarkan kriteria BPS dan Sayogyo, sebagian besar rumah tangga petani ubikayu berada pada golongan hidup layak dan sejahtera.

2. Faktor-faktor yang mempengaruhi tingkat kesejahteraan rumah tangga petani ubikayu di Desa Gunung Agung Kecamatan Terusan Nunyai Kabupaten Lampung Tengah yaitu jumlah pekerjaan, pengalaman berusahatani, dan pendapatan rumah tangga.

\section{SARAN}

Untuk menjamin keberlanjutan usahatani ubikayu dan tingkat kesejahteraan rumah tangga petani ubikayu maka kebijakan yang diperlukan :

1. Pengembangan program intensifikasi ubikayu melalui penggunaan bibit (stek) 
varietas unggul, penggunaan pupuk berimbang, peningkatan ketersediaan dan akses petani pada sarana produksi, bantuan modal usahatani, jaminan pasar ubikayu dengan harga bersaing stabil dan pengembangan industri tepat guna untuk pengolahan ubikayu skala kecil.

2. Pengembangan kelembagaan kemitraan agribisnis ubikayu yang terbuka, akuntabel, jujur, dan bermartabat dengan melibatkan masyarakat petani ubikayu, pabrikan, akademisi, dan pemerintah dan media massa guna meningkatkan kesejahteraan petani sehingga memiliki daya saing agribisnis ubikayu dari hulu hingga hilir.

3. Pentingnya kerjasama yang bersinergis dengan pembagian kerja antar pengampu kepentingan yaitu pemerintah, dunia usaha, dan masyarakat dalam agribisnis ubikayu sangat diperlukan

\section{DAFTAR PUSTAKA}

Asmarantaka R W. 2007. Analisis Ekonomi Rumahtangga Petani Tanaman Pangan di Provinsi Lampung. Jurnal Agribisnis dan Ekonomi Pertanian 1(1):1-18

Badan Pusat Statistik Provinsi Lampung. 2008. Lampung Dalam Angka 2008. http://lampung.bps.go.id. Diakses pada tanggal 3 Mei 2019

Badan Pusat Statistik Provinsi Lampung. 2014. Lampung Dalam Angka 2014. http://lampung.bps.go.id. Diakses pada tanggal 20 November 2019 pukul 20.00 WIB.

Badan Pusat Statistik. 2017. Indikator Kesejahteraan Rakyat 2017. Badan Pusat Statistik. Jakarta

Balakrishnama, Naidu. 2013. Impact of Agricultural Credit on Agricultural Production and Productivity. Dalam Asia Pasific Journal of Social Sciences, Vol 5 (1).

Chenery HB, Syrquin M. 1975. Pattern of Development 1950-1970. Word Bank
Working Paper. Washington DC: World Bank.

Hastuti DHD dan A Rahim. 2008. Pengantar, Teori, dan Kasus Ekonomika Pertanian. Penebar Swadaya. Jakarta.

Igweoscar O, 2014. Effect of Contract Farming on Productity and Welfare of CassavaBased Farmers in South Eastern Nigeria. European Journal of Business and Management www.iiste.org ISSN 22221905 (Paper) ISSN 2222-2839 (Online) Vol.6(7):334-339

Iqbal AM, Lestari DAH, Soelaiman A. 2014. Pendapatan dan Kesejahteraan Rumah Tangga Petani Ubi Kayu di Kecamatan Sukadana Kabupaten Lampung Timur. Jurnal Ilmu-ilmu Agribisnis 2(3): 246-25

Ginting, Salmina W. 2010. Transformasi Spasial dan Diversifikasi Ekonomi pada Wilayah Peri Urban di Indonesia. Jurnal Arsitektur dan Perkotaan. Koridor 1(7): 6064.

Kahya M. 2012. Structural change, income distribution and poverty in ASEAN-4 countries [tesis]. Lund University.

Marisa dan Hutabarat, 1988. Keberagaman Sumber Pendpatan Rumah Tangga dan Dampaknya Terhadap Kemampuan Ekonomi Rumah Tangga Petani. Jurnal Agroekonomi 12(2) PERHEPI, Yokyakarta.

Mwaura, F. 2014. Efect of Farmer Group Membership on Agriculture Technology Adoption and Crop Productivity in Uganda. African Crop Science Journal 22 (4): 917- 927

Makki MF. 1994. Transformasi Struktur Perekonomian Indonesia dan Implikasinya terhadap Distribusi Pendapatan. Jakarta: Karya Ilmiah Program Perencanaan Nasional LPEM UI.

Mukhtar U (2012). Economic analysis of poutry-egg production in Bauchi local government area, Bauchi state, Nigeria. An M.Sc Thesis of Department of 
Agricultural Economics, Ahmadu Bello Univeristy Zaria.

Ndakularak E., Setiawina N D, dan Djayastra IK. 2014. Analisis Faktor-Faktor yang Mempengaruhi Kesejahteraan Masyarakat Kabupaten/Kota di Provinsi Bali. Jurnal Ekonomi dan Bisnis Universitas Udayana 03(3):140-153.

Rambe A, Hartoyo dan karsin ES. 2008. Analisis Alokasi Pengeluaran dan Tingkat Kesejahteraan Keluarga (Studi di Kecamatan Medan Kota, Sumatera Utara). Jurnal Ilmu Keluarga dan Konsumen 1(1):16-28

Rizal A, Rosidah, dan Fathira G. 2018. Potret Tingkat Kesejahteraan Rumah Tangga Pembudidaya Ikan di Ciganjur Jakarta Selatan. Jurnal Ilmu-ilmu Sosial dan Humaniora. 20(1): 39-44

Roedjito, D. 1989. Kajian Penelitian Gizi. Jakarta. Mediyatama Sarana Perkasa

Sajogyo, T. 1997. Garis Kemiskinan dan Kebutuhan Minimum Pangan. LPSB-IPB. Bogor.

Saliem HP, Mayrowani, Sumaryanto GS. Hardono TB, Purwantini Y, Marisa, dan Hidayat D. 2005. Pengaruh Pola Diversifikasi Tanaman Pangan Terhadap Pendapatan Rumah Tangga Petani. Pusat Studi Ekonomi Pertanian. PSE Bogor, Bogor.

Syakina FN, Indriani, Y dan Affandi MI, 2019. Analisis Pendapatan, Kesejahteraan Rumah Tangga dan Strategi Pengembangan Usaha Budidaya Lele di Kecamatan Natar Kabupaten Lampung Selatan. Jurnal Ilmu-ilmu Agribisnis 7(1):60-67

Yunus, Hadi Sabari. 2008. Dinamika Wilayah Peri-Urban: Determinan Masa Depan Kota. Yokyakarta: Pustaka Pelajar

Zakaria, WA. 2018. Model Kelembagaan Kemitraan Agribisnis Ubikayu di Provinsi Lampung. Laporan Hibah Profesor. Universitas Lampung. Bandar Lampung. 